\title{
Eight Species of Poaceae Are Hosting Different Genetic and Pathogenic Strains of Sugarcane Mosaic Virus in the Everglades Agricultural Area
}

\author{
Martha Hincapie, ${ }^{1}$ Sushma Sood,${ }^{2}$ Dimitre Mollov, ${ }^{3}$ D. Calvin Odero, ${ }^{4}$ Michael Grisham, ${ }^{5}$ and Philippe Rott ${ }^{1,6,7, \dagger}$ \\ ${ }^{1}$ University of Florida, Everglades Research and Education Center, Plant Pathology Department, Belle Glade, FL 33430, U.S.A. \\ ${ }^{2}$ USDA-ARS, Sugarcane Field Station, Canal Point, FL 33438, U.S.A. \\ ${ }^{3}$ USDA-ARS, National Germplasm Resources Laboratory, Beltsville, MD 20705, U.S.A. \\ ${ }^{4}$ University of Florida, Everglades Research and Education Center, Agronomy Department, Belle Glade, FL 33430, U.S.A. \\ ${ }^{5}$ USDA-ARS, Sugarcane Research Unit, Houma, LA 70360, U.S.A. \\ ${ }^{6}$ CIRAD, UMR PHIM, 34398 Montpellier, France \\ ${ }^{7}$ PHIM Plant Health Institute, Univ Montpellier, CIRAD, INRAE, Institut Agro, IRD, Montpellier, France \\ Accepted for publication 22 February 2021.
}

\begin{abstract}
Sugarcane mosaic virus (SCMV) was detected by reverse transcription polymerase chain reaction in eight different species of the Poaceae family in the Everglades Agricultural Area (EAA) of south Florida: broadleaf signalgrass (Urochloa platyphylla), Columbus grass (Sorghum almum), goosegrass (Eleusine indica), maize (Zea mays), sorghum (Sorghum bicolor), St. Augustine grass (Stenotaphrum secundatum), southern crabgrass (Digitaria ciliaris), and sugarcane (Saccharum interspecific hybrids). Based on their coat protein (CP) gene sequence, 62 isolates of SCMV from Florida and 29 worldwide isolates representing the known genetic diversity of this virus were distributed into eight major phylogenetic groups. SCMV isolates infecting Columbus grass, maize, and sorghum in Florida formed a unique group, whereas virus isolates infecting sugarcane in the United States (Florida and Louisiana) clustered with isolates from other countries. Based on the entire genome coding region, SCMV isolates infecting sugarcane in Florida were closest to virus isolates infecting sorghum species or St. Augustine

grass. Virus isolates from Columbus grass, St. Augustine grass, and sugarcane showed different virulence patterns after mechanical inoculation of Columbus grass, St. Augustine grass, and sugarcane plants, thus proving that these isolates were different pathogenic strains. Sugarcane was symptomless and tested negative for SCMV by tissue blot immunoassay after inoculation with crude sap from SCMV-infected Columbus grass, indicating that Columbus grass was not a reservoir for SCMV infecting sugarcane in the EAA. Close CP sequence identity between isolates of SCMV from Columbus grass, maize, and sorghum suggested that the same virus strain was naturally spreading between these three plants in south Florida.

Keywords: broadleaf signalgrass, Columbus grass, disease resistance, goosegrass, host, maize, pathogen detection, sorghum, St. Augustine grass, southern crabgrass, sugarcane, Sugarcane mosaic virus, virus strain, virulence
\end{abstract}

Sugarcane mosaic virus (SCMV) infects naturally many wild and cultivated grasses belonging to $\geq 21$ different genera of the family Poaceae (Koike and Gillaspie 1989). Sugarcane (Saccharum spp. interspecific hybrids), sorghum (Sorghum bicolor [L.] Moench), and maize (Zea mays L.) are the most economically important crops affected by this virus worldwide. In central Florida nurseries in 2010, SCMV was detected in red Maranta or red-veined prayer plant (Maranta leuconeura var. erythroneura É. Morren), a new host belonging to the Marantaceae family. The symptomatic Maranta plants in these nurseries were grown from cuttings imported from Costa Rica (Baker et al. 2010). More recently, SCMV was also found in China in canna (Canna indica L.), a monocotyledonous plant of the Cannaceae family, and in pumpkin (Cucurbita moschata Duchesne),

${ }^{\dagger}$ Corresponding author: P. Rott; philippe.rott@cirad.fr

Funding: This research would not have been possible without funding provided by the Florida Sugar Cane League (project number 00107475, fund number F000057, and fund number 660684). The work is supported by the U.S. Department of Agriculture National Institute of Food and Agriculture (project Hatch/Rott FLA-BGL005404).

*The $\boldsymbol{e}$-Xtra logo stands for "electronic extra" and indicates that two supplementary tables and three supplementary figures are published online.

The author(s) declare no conflict of interest.

This article is in the public domain and not copyrightable. It may be freely reprinted with customary crediting of the source. The American Phytopathological Society, 2021. a dicotyledonous plant of the Cucurbitaceae family (Li et al. 2019; Tang et al. 2018; Zhao et al. 2019).

In Florida, SCMV was first reported in sugarcane in 1919 by Brandes (Saladini and Zettler 1972a). Subsequently, this virus was also found in Columbus grass (Sorghum $\times$ almum Parodi), gammagrass (Tripsacum sp.), hairy crabgrass (Digitaria sanguinalis [L.] Scop.), sorghum, St. Augustine grass (Stenotaphrum secundatum [Walter] Kuntze), and sweet corn (Zea mays L. var. saccharata) (Boukari et al. 2021; Mollov et al. 2016; Saladini and Zettler 1972a, b; Todd 1964).

SCMV is a Potyvirus in the family Potyviridae. The genome of SCMV is monopartite positive-sense single-stranded RNA of approximately 9,500 nucleotides forming a single open reading frame (ORF). This long ORF encodes a single polyprotein that is cleaved into 10 multifunctional proteins (Braidwood et al. 2019). An additional short ORF (pipo) is embedded within the P3 gene and translated in the +2 reading frame (Chung et al. 2008). The coat protein $(\mathrm{CP})$ gene of the virus is located at the $3^{\prime}$ end of the genome. Historically, the $\mathrm{CP}$ has often been used for diagnosis of SCMV and characterization of its genetic diversity (Alegria et al. 2003; de Souza et al. 2012; Gómez et al. 2009; Handley et al. 1998; Marie-Jeanne et al. 2000; Moradi et al. 2017; Yang and Mirkov 1997). More recently, full genome sequencing has been used to investigate variation within the virus and especially to analyze genomic evolution (Braidwood et al. 2019; He et al. 2020; Wamaitha et al. 2018; Yahaya et al. 2019). These studies revealed that SCMV is highly variable, with several recombination hotspots along its genome. The recently reported new virus strain from canna 
has been identified as a recombinant virus between an isolate infecting sugarcane and an isolate infecting maize (Li et al. 2019).

Mosaic disease of sugarcane caused by SCMV is currently managed with resistant cultivars in the Everglades Agricultural Area (EAA), and the virus was not found in commercial plantings in a recent metagenomics study (Filloux et al. 2018). Mosaic symptoms are sometimes seen in the EAA on maize, but the disease does not seem to affect maize production in this region. In contrast, severe outbreaks of mosaic have occurred since 2013 on St. Augustine grass (cultivar Floratam), a perennial lawn grass widely grown in Florida (Harmon 2015). Leaf blades of affected plants show contrasting shades of green, chlorotic, and necrotic tissue. Virus incidence with severe symptoms on St. Augustine grass may destroy the entire lawn.

At least 14 pathogenic strains (A to $\mathrm{N}$ ) have been reported for SCMV (Koike and Gillaspie 1989). Nine isolates of the virus collected in south Florida in the 1970s from gammagrass, hairy crabgrass, St. Augustine grass, sugarcane, and sweet corn were attributed to strain $\mathrm{E}$ of SCMV, based on inoculation to differential hosts, including different varieties of sorghum, sweet corn, and johnsongrass (Sorghum halepense [L.] Pers.) (Saladini and Zettler 1972a, b).

The overall aim of this work was to better understand the epidemiology of SCMV in south Florida. To reach this objective, we collected 62 SCMV isolates from eight different hosts in the EAA and first compared their genetic diversity at the $\mathrm{CP}$ level. The full coding genome of four isolates from Florida (two from St. Augustine grass and two from sugarcane), and two historical isolates from sugarcane in Louisiana was also determined by high-throughput sequencing (HTS). Both $\mathrm{CP}$ and full genome sequences were compared with the corresponding sequences of SCMV isolates reported worldwide (GenBank). Finally, we investigated the capacity of cross-infection and production of symptoms of representative isolates from Columbus grass, St.

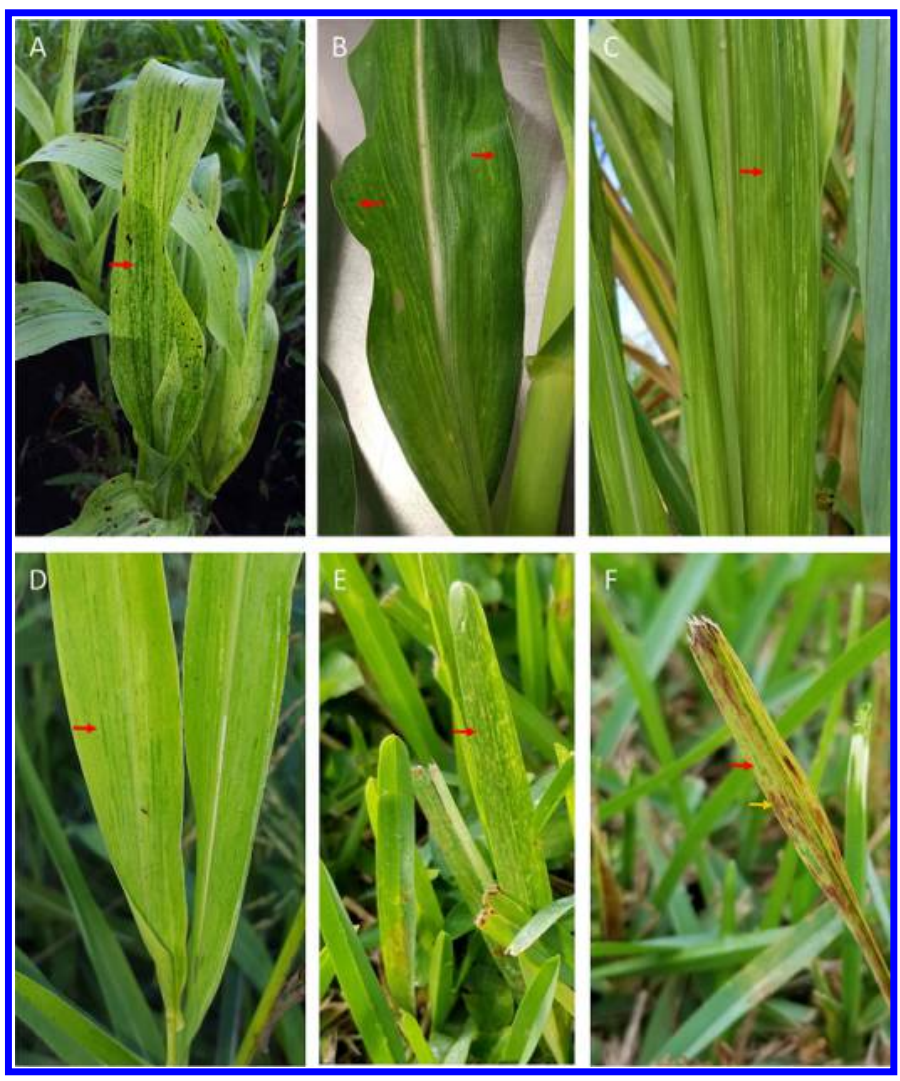

Fig. 1. Symptoms of mosaic on five species of Poaceae in Florida. A, Sorghum (Sorghum bicolor). B, Maize (Zea mays). C, Sugarcane (Saccharum spp. interspecific hybrid). D, Columbus grass (Sorghum almum). E and F, St. Augustine grass (Stenotaphrum secundatum). Mosaic symptoms include various patterns of green color (red arrow in $\mathbf{A}$ to $\mathbf{F}$ ) and necrosis (yellow arrow in $\mathbf{F}$ ).
Augustine grass, and sugarcane by mechanical inoculation to Columbus grass, maize, sorghum, St. Augustine grass, and sugarcane plants.

\section{MATERIALS AND METHODS}

Leaf samples with mosaic symptoms. Leaves exhibiting mosaic symptoms were collected from eight plant species within a 50-mile radius of the EAA. A collection of 62 plants was obtained, which included two samples of southern crabgrass (Digitaria ciliaris [Retz.] Koeler), one of goosegrass (Eleusine indica [L.] Gaertn.), six of maize, 13 of St. Augustine grass, 16 of Columbus grass, 16 of sorghum, seven of sugarcane, and one of broadleaf signalgrass (Urochloa platyphylla [Munro ex C. Wright] R. D. Webster) (Supplementary Table S1 and Figs. 1 and 2).

RNA extraction and detection of sugarcane mosaic virus by reverse transcription PCR. Total RNA was extracted from $100 \mathrm{mg}$ of leaves with a Qiagen RNeasy Plant mini kit (Qiagen, USA), according to the manufacturer's protocol. Each RNA sample was suspended in $40 \mu \mathrm{l}$ of ribonuclease-free water and stored at $-20^{\circ} \mathrm{C}$ until further use. Detection of SCMV was performed with primer pair Oligo 1n/Oligo $2 \mathrm{n}$ as described in Table 1. Reverse transcription PCR (RT-PCR) products were analyzed by $1 \%$ agarose gel electrophoresis (Fig. 3). The RT-PCR amplicons were purified with a QIAquick PCR purification kit (Qiagen) and sequenced bidirectionally with amplification primers by Eton Bioscience (San Diego, CA). New SCMV sequences were compared with those already published (GenBank) via Blast search (https://blast.ncbi.nlm.nih.gov/Blast.cgi).

Amplification and sequencing of the $\mathrm{CP}$ gene of sugarcane mosaic virus isolates. Samples that tested positive for SCMV by RT-PCR with detection primers Oligo 1n/Oligo 2 n were used for two-step amplification of the entire CP gene of the virus. PCR assays were performed after an initial reverse transcription step, followed by PCR with primers SCMV-NIb-482-F/SCMV-3'UTR-606-R (Table 1; Fig. 3). The negative samples were retested with a different primer set, SCMV-F6/SCMV-R6. RT-PCR products were subjected to $1 \%$ agarose gel electrophoresis, and amplicons were gel purified and sequenced as described previously. The CP gene sequences were aligned and compared with published SCMV sequences

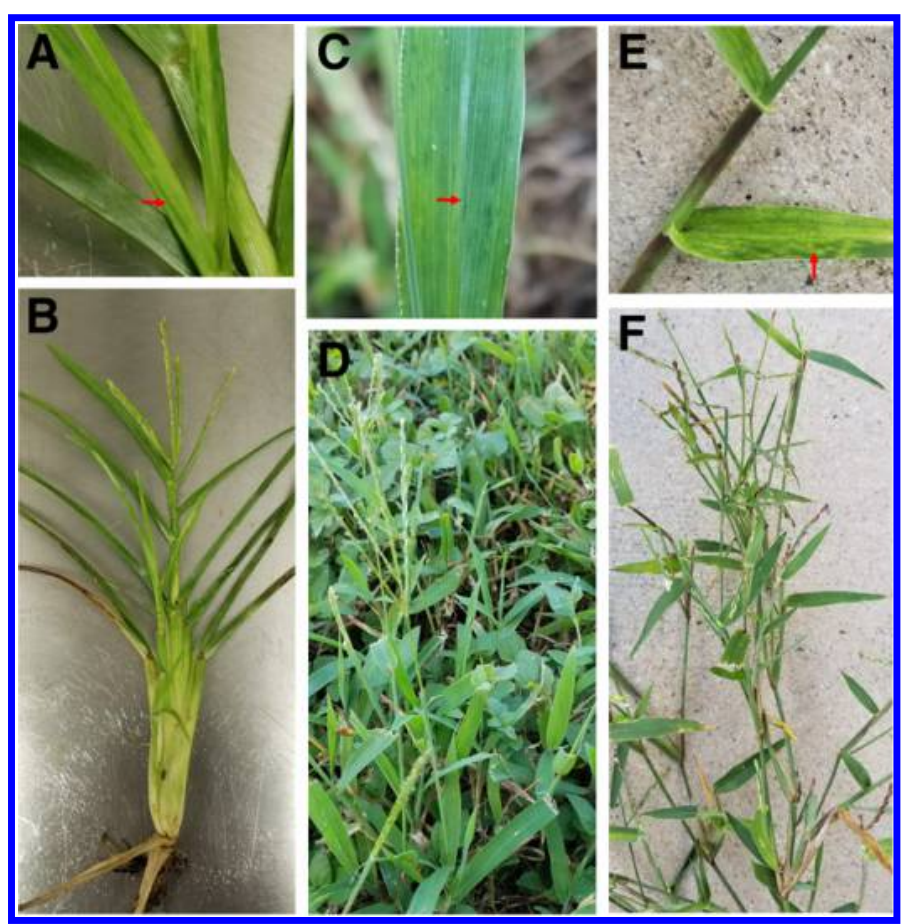

Fig. 2. Symptoms of mosaic on three species of Poaceae in Florida. A and B, Goosegrass (Eleusine indica). $\mathbf{C}$ and D, Southern crabgrass (Digitaria ciliaris). $\mathbf{E}$ and $\mathbf{F}$, Broadleaf signalgrass (Urochloa platyphylla). Mosaic symptoms include various patterns of green color (red arrows in $\mathbf{A}, \mathbf{C}$, and $\mathbf{E}$ ). 
retrieved from GenBank in Geneious prime software (Biomatters Ltd NZ). Several sequences obtained with primers SCMV-F6/SCMV-R6 contained unidentified nucleotides at the $3^{\prime}$ end of the CP gene. To resolve these ambiguities, additional amplification and sequencing were performed with primers SCMV-DF/SCMV-R6 (Table 1; Fig. $3)$. The CP gene sequences of 58 SCMV isolates obtained in this study by RT-PCR and sequencing were deposited in GenBank under accession numbers MT725503 to MT725560 (Supplementary Table $\mathrm{S} 1)$. The $\mathrm{CP}$ gene sequence of the four remaining isolates from Florida was determined by HTS as described below.

HTS of the full genome of six isolates of SCMV from Florida and Louisiana. The entire genome of the following six SCMV isolates was sequenced by HTS: SAG-CED and SAG-CYP from St. Augustine grass in Florida, SC-2086 Su and SC-Halalii Su from sugarcane in Florida, and POJ234 strain A and POJ234 strain B from sugarcane in Louisiana (Supplementary Tables S1 and S2). The latter two isolates from Louisiana were added to this study because they represented historical isolates that were maintained at the U.S. Department of Agriculture-Agricultural Research Service (USDA-ARS) in Houma, Louisiana by vegetative propagation of sugarcane for $>70$ years. Total RNA was extracted from symptomatic leaves with the RNeasy Qiagen mini plant extraction kit and sent to SeqMatic (Fremont, CA) for ribosomal RNA depletion, deoxyribonuclease treatment, and complementary DNA library preparation. Libraries were sequenced on an Illumina NextSeq 500 platform as 75-nt single-end reads. Sequence reads were assembled into contigs in CLC Genomic Workbench 11.0 (Qiagen). BLASTx comparisons of contigs were performed with a local NCBI database under the CLC platform. Geneious R11 (Biomatters, New Zealand) was then used to finalize additional assemblies. The assembled genome sequences obtained by HTS were deposited in GenBank with the following accession numbers: MT701606 (SAG-CED), MT701607 (SAG-CYP), MT701608 (SC-2086 Su), MT701609 (SC-Halalii Su), MT701610 (POJ234 strain A), and MT701611 (POJ234 strain B).

Determination of percentage identity between virus sequences and phylogenetic analyses. Nucleotide sequence identities and amino acid sequence similarities were determined for the $\mathrm{CP}$ of 91 isolates of SCMV (Supplementary Tables S1 and S2): 62 isolates from Florida obtained in this study ( 58 sequences by RT-PCR and four by HTS), two isolates from Louisiana obtained in this study by HTS, and 27 sequences retrieved from the GenBank database. Nucleotide and amino acid sequence identities were also determined for the entire coding region of the six isolates of SCMV sequenced in this study (four from Florida and two from Louisiana) and 21 isolates from GenBank. Corresponding sequences of SCMV isolates were aligned, and percentage identities were determined in Clustal W. Maximum likelihood phylogenetic trees were inferred for the $\mathrm{CP}$ and the entire coding region of SCMV in MEGA X software with substitution model Tamura-Nei selected as best-fit model and 1,000 bootstraps (Kumar et al. 2018; Tamura and Nei 1993).

Inoculation of five species of Poaceae with SCMV. Seeds of Columbus grass, sorghum, and maize were planted in vented nursery trays $(51 \times 36 \times 10 \mathrm{~cm}$; Kadon Corp. $)$ or in 5-gallon pots containing potting soil (Nursery Supply Inc.). Three weeks after seed germination, plants were thinned to a maximum of 20 plants per tray and four plants per pot. Single-bud cuttings of sugarcane and St.

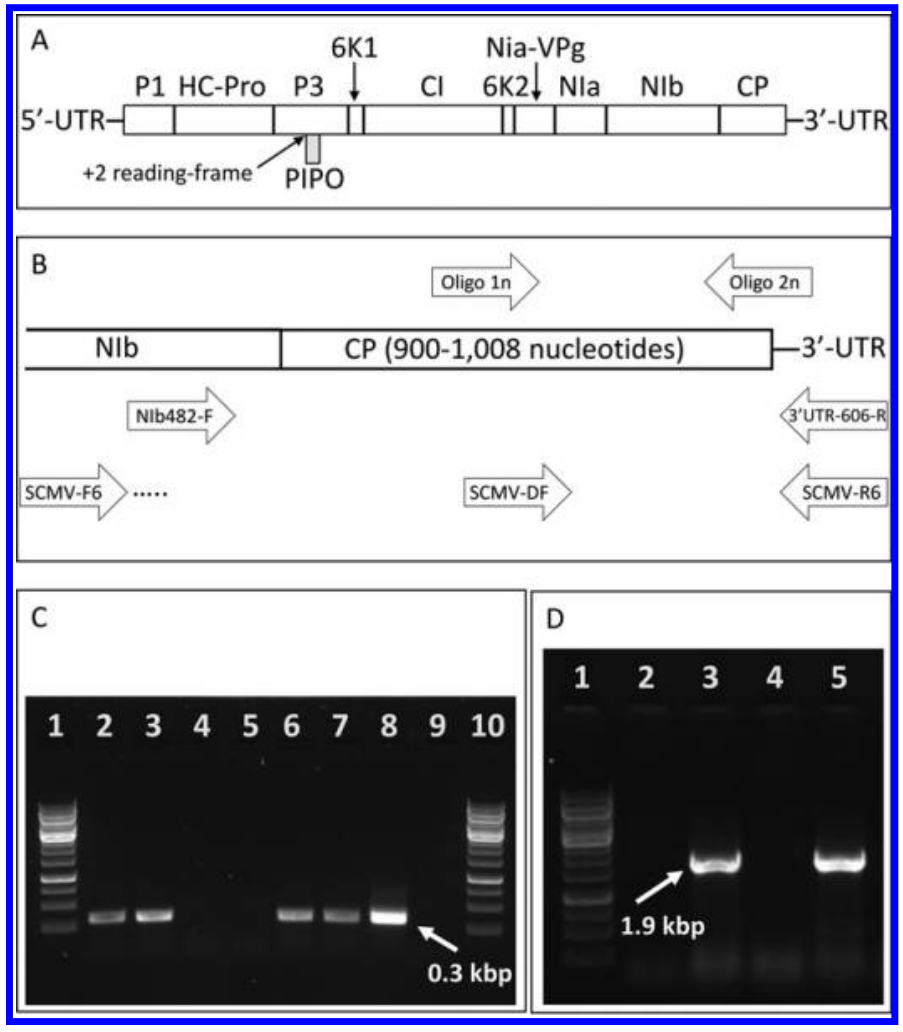

Fig. 3. Genome structure and amplification of the $3^{\prime}$ end region of sugarcane mosaic virus (SCMV) by reverse transcription PCR (RT-PCR). A, Proteins encoded by SCMV: P1, P1 protein; HC-Pro, helper component proteinase; $\mathrm{P} 3$, P3 protein; PIPO, PIPO protein; 6K1, $6 \mathrm{~K} 1$ protein; CI, cylindrical inclusion protein; $6 \mathrm{~K} 2,6 \mathrm{~K} 2$ protein; Nia-VPg, nuclear inclusion A-VPg protein; $\mathrm{NIa}$, nuclear inclusion A protein; NIb, nuclear inclusion B protein; $\mathrm{CP}$, coat protein. B, Genome location of the primers used to detect SCMV or to amplify the $3^{\prime}$ end region of the genome. C, Detection of SCMV by RT-PCR with primer pairs Oligo 1n/Oligo 2n): lanes 1 and 10, 1-kbp ladder; lanes 2, 3, and 6 to 8 , plant samples with mosaic symptoms; lanes 4, 5, and 9, symptomless plant samples. D, Amplification of the CP of SCMV by RT-PCR with primers SCMV-F6/SCMV-R6: lane 1, 1-kbp ladder; lanes 2 and 4, virus-free sorghum samples; and lanes 3 and 5 , sorghum samples infected by SCMV.

TABLE 1. Primer pairs and PCR conditions used for detection and for coat protein (CP) amplification of sugarcane mosaic virus (SCMV)

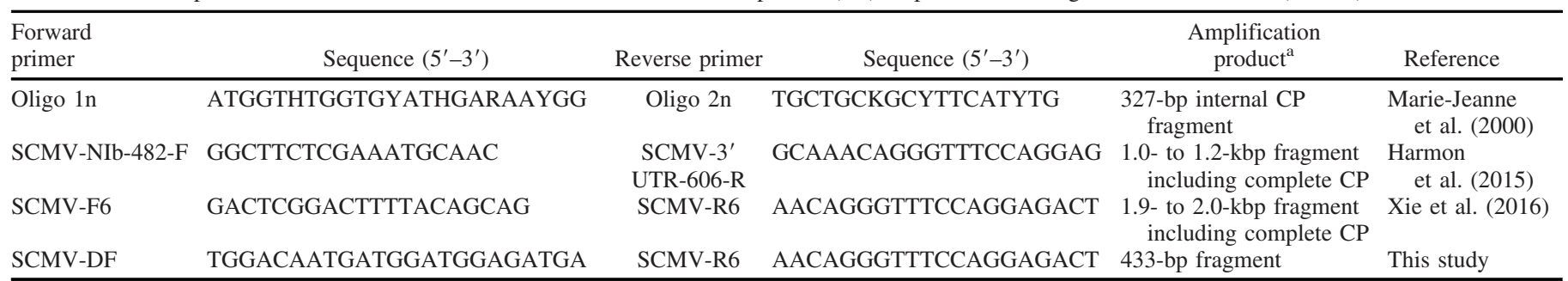

${ }^{a}$ Reverse transcription PCR (RT-PCR) assay with primers Oligo 1n/oligo 2n was performed with a OneStep RT-PCR kit (Qiagen) and amplification conditions reported by Marie-Jeanne et al. (2000). PCR assays with the three other primer sets were performed with complementary DNA (cDNA) obtained with the Promega's GoScript Reverse Transcription System according to the manufacturer's protocol. Amplification was done in a final volume of $25 \mu l$ containing $2.5 \mu \mathrm{l}$ of eluted cDNA, $12.5 \mu \mathrm{l}$ of GoTaq Colorless Master Mix $2 \times$ (Promega), $1 \mu \mathrm{l}$ of $10 \mu \mathrm{M}$ of forward primer, $1 \mu \mathrm{l}$ of $10 \mu \mathrm{M}$ of reverse primer, and $8 \mu \mathrm{l}$ of nuclease-free water. For primer set SCMV-NIb-482-F/SCMV-3'UTR-606-R, the thermal cycling conditions were $94^{\circ} \mathrm{C}$ for 3 min, 30 cycles of $94^{\circ} \mathrm{C}$ $(1 \mathrm{~min}), 56^{\circ} \mathrm{C}(1 \mathrm{~min})$, and $72^{\circ} \mathrm{C}(1 \mathrm{~min})$, and a final extension of $72^{\circ} \mathrm{C}$ for $10 \mathrm{~min}$. PCR conditions of SCMV-F6/SCMV-R6 were those reported by Xie et al. (2016). The thermal conditions for primers SCMV-DF/SCMV-R6 were $94^{\circ} \mathrm{C}$ for $3 \mathrm{~min}, 35 \mathrm{cycles}$ of $94^{\circ} \mathrm{C}(1 \mathrm{~min}), 51^{\circ} \mathrm{C}(1 \mathrm{~min})$, and $72^{\circ} \mathrm{C}(30 \mathrm{~s})$, and a final extension of $72^{\circ} \mathrm{C}$ for $10 \mathrm{~min}$. 
Augustine grass plugs were planted in 5-gallon pots containing the same potting soil, with four plants or plugs per pot. All plants were grown in a greenhouse with natural light conditions and temperatures varying from 16 to $35^{\circ} \mathrm{C}$ at the USDA-ARS sugarcane field station at Canal Point, Florida. Columbus grass, sorghum, and maize plants were inoculated when approximately 3 weeks old (four or five developed leaves). Sugarcane was inoculated when approximately 6 weeks old (four or five fully developed leaves), and St. Augustine grass was inoculated 2 weeks after the grass plugs were planted.

The inoculations were performed in six experiments between May 2018 and September 2019 (Table 2). The total number of inoculated plants varied between plant species and experiments, and inoculated plants of each species were equally distributed in three or four groups containing plants of each species. These groups were randomly distributed in the greenhouse.

Preparation of SCMV inoculum and mechanical plant inoculation. Leaves from plants showing mosaic symptoms were cut into small pieces (about $2 \times 3 \mathrm{~cm}$ ) in the laboratory and stored at $-20^{\circ} \mathrm{C}$ until further use or were frozen with dry ice and ground to a powder before storage. Before inoculation, frozen leaves or frozen powdered leaves were homogenized in a 1.2-liter Waring blender (model $7011 \mathrm{HG}$ ) containing ice-cold $0.01 \mathrm{M}$ potassium phosphate buffer ( $\mathrm{pH} 7.0)$ (1:1, wt/vol). Blended leaf tissue was filtered twice through a cheesecloth, and the resulting crude juice homogenate was used as an inoculum source. The paint sprayer inoculation method was used to inoculate plants in experiments 1 to 3 (Table 2). This method has been used for many years at the USDA-ARS Sugarcane Field Station at Canal Point to screen sugarcane for resistance to mosaic (Dean 1963). It allows one to inoculate many plants rapidly with the same inoculum source. The abrasive pad rubbing method was used to inoculate plants in experiments 4 to 6 (Table 2). This method, described for inoculation of sugarcane by Srisink et al. (1994), allows one to inoculate plants with a limited amount of inoculum, which was especially the case herein for naturally SCMV-infected St. Augustine grass. Leaves of control plants were sprayed or rubbed with the homogenization buffer only.

Detection of SCMV by tissue blot immunoassay. At the end of inoculation experiments 3 to 6 (Table 2), the upper most developed leaf of all inoculated plants was collected and used for tissue blot immunoassay. Imprints of each leaf midrib were made on a 0.45 $\mu \mathrm{m}$ pore-size nitrocellulose membrane (Bio-Rad) and processed as described for sugarcane yellow leaf virus (Lin et al. 1990; Schenck et al. 1997), except sugarcane yellow leaf virus antibodies were replaced by SCMV antibodies. SCMV antibodies specific for strain E (American Type Culture Collection, Rockville, MD) were used at 1:2,000 dilution.

\section{RESULTS}

Detection of SCMV in eight species of Poaceae. From 2015 to 2019, variable mosaic symptoms with contrasting green shades were observed on leaf blades of eight different species of Poaceae in several locations of the EAA in south Florida (Figs. 1 and 2). Specific symptom patterns were usually not associated with a plant species but rather with a plant variety or cultivar, with a few exceptions. Numerous light green to yellow spotting was observed only on sorghum (Fig. 1A). Broadleaf signalgrass, St. Augustine grass, and sorghum often showed numerous short streaks on the leaf blade (Figs. 1A and $\mathrm{E}$, and 2E). Dark green streaks or stripes were usually found on Columbus grass, goosegrass, southern crabgrass, maize, and sugarcane (Figs. 1B to D and 2A to C). In addition to light green streaks, only St. Augustine grass cultivar Floratam grown in lawns exhibited extensive necrotic lesions (Fig. 1F). This leaf necrosis was not seen on common St. Augustine grass growing in grasslands on muck soils.

SCMV was detected by RT-PCR (primers oligo $1 \mathrm{n} / 2 \mathrm{n}$ ) in broadleaf signalgrass (one sample), Columbus grass (16 samples), goosegrass (one sample), maize (six samples), sorghum (16 samples), southern crabgrass (two samples), St. Augustine grass (11 samples), and sugarcane (five samples). SCMV sequences were found by HTS in two additional samples of St. Augustine grass (isolates SAG-CED and SAG-CYP) and two additional samples from sugarcane (isolates SC-2086 Su and SC-Halalii Su). All 62 Florida isolates shared $>90 \%$ nucleotide identities with sequences of SCMV isolates in the GenBank database. Sequences of SCMV were also obtained by HTS from the two historical symptomatic sugarcane varieties

TABLE 2. Infection of five Poaceae species by sugarcane mosaic virus (SCMV) after mechanical inoculation with virus isolates from Columbus grass, St. Augustine grass, and sugarcane

\begin{tabular}{|c|c|c|c|c|c|c|c|c|}
\hline \multirow{2}{*}{$\begin{array}{l}\text { SCMV inoculum } \\
\text { source }^{\mathrm{a}}\end{array}$} & \multirow{2}{*}{$\begin{array}{l}\text { Plant species } \\
\text { inoculated }^{\mathrm{b}}\end{array}$} & \multicolumn{7}{|c|}{ Number of plants with mosaic symptoms/total number of inoculated plants in experiments ${ }^{\mathrm{c}}$} \\
\hline & & 1 & 2 & 3 & 4 & 5 & 6 & $1-6$ \\
\hline \multirow[t]{5}{*}{ Columbus grass } & Columbus grass & $55 / 61$ & $39 / 50$ & $17 / 34$ & $9 / 12$ & $14 / 16$ & $15 / 16$ & $149 / 189(79 \%)$ \\
\hline & Maize & $4 / 16$ & $21 / 35$ & $26 / 26$ & $12 / 12$ & - & - & $63 / 89(71 \%)$ \\
\hline & Sorghum & $40 / 40$ & $3 / 26$ & $25 / 25$ & $12 / 12$ & - & - & $80 / 103(78 \%)$ \\
\hline & St. Augustine grass & - & - & - & - & $7 / 16$ & $5 / 16$ & $12 / 32(38 \%)$ \\
\hline & Sugarcane & $0 / 22$ & $0 / 13$ & $0 / 36$ & $0 / 12$ & $0 / 16$ & $0 / 16$ & $0 / 115(0 \%)$ \\
\hline \multirow[t]{3}{*}{ St. Augustine grass } & Columbus grass & - & - & - & - & $0 / 16$ & $0 / 16$ & $0 / 32(0 \%)$ \\
\hline & St. Augustine grass & - & - & - & - & $16 / 16$ & $16 / 16$ & $32 / 32(100 \%)$ \\
\hline & Sugarcane & - & - & - & - & $16 / 16$ & $14 / 16$ & $30 / 32(94 \%)$ \\
\hline \multirow[t]{5}{*}{ Sugarcane } & Columbus grass & - & - & $0 / 38$ & $0 / 12$ & $0 / 16$ & $0 / 16$ & $0 / 82(0 \%)$ \\
\hline & Maize & - & - & $12 / 35$ & $3 / 12$ & - & - & $15 / 47(32 \%)$ \\
\hline & Sorghum & - & - & $6 / 33$ & $2 / 12$ & - & - & $8 / 45(18 \%)$ \\
\hline & St. Augustine grass & - & - & - & - & $5 / 16$ & $7 / 16$ & $12 / 32(38 \%)$ \\
\hline & Sugarcane & - & - & $23 / 34$ & $12 / 12$ & $11 / 16$ & $16 / 16$ & $62 / 78(79 \%)$ \\
\hline \multirow[t]{5}{*}{ Buffer (control) } & Columbus grass & $0 / 20$ & $0 / 50$ & $0 / 40$ & $0 / 12$ & $0 / 16$ & $0 / 16$ & $0 / 154(0 \%)$ \\
\hline & Maize & $0 / 7$ & $0 / 10$ & $0 / 40$ & $0 / 12$ & - & - & $0 / 69(0 \%)$ \\
\hline & Sorghum & - & $0 / 37$ & $0 / 39$ & $0 / 12$ & - & - & $0 / 88(0 \%)$ \\
\hline & St. Augustine grass & - & - & - & - & $0 / 16$ & $0 / 16$ & $0 / 32(0 \%)$ \\
\hline & Sugarcane & $0 / 10$ & $0 / 8$ & $0 / 40$ & $0 / 12$ & $0 / 16$ & $0 / 16$ & $0 / 102(0 \%)$ \\
\hline
\end{tabular}

\footnotetext{
${ }^{a}$ SCMV isolate SAL-EREC2 (Columbus grass), SCMV isolate SAG-EREC3 (St. Augustine grass), and SCMV isolate SC-2086 EG (sugarcane).

${ }^{\mathrm{b}}$ Maize cultivar Passion for experiments 1 to 4; sorghum cultivar MN1054 for experiments 1, 3, and 4 and cultivar MN50 for experiment 2; St. Augustine grass cultivar Floratam for experiments 5 and 6; sugarcane cultivar CP72-2086 for experiments 1 and 2 and cultivar CL68-575 for experiments 3 to 6. Plants were inoculated at the following dates: 20 May 2018 (experiment 1), 20 June 2018 (experiment 2), 12 September 2018 (experiment 3), 4 March 2019 (experiment 4), 8 July 2019 (experiment 5), and 25 September 2019 (experiment 6).

${ }^{\mathrm{c}}$ Symptoms were recorded 4 to 5 weeks post mechanical inoculation, with the exception of Columbus grass and sugarcane in experiment 3 (data recorded 9 weeks postinoculation). In experiments 3 to 6, all plants with mosaic symptoms tested positive for SCMV by tissue blot immunoassay, whereas all symptomless plants and plants inoculated with the buffer were negative.
} 
originating from Louisiana that were infected by two different strains of the virus.

Genetic variability of SCMV in Florida based on the CP sequence. The size of the $\mathrm{CP}$ sequence of the 62 isolates of SCMV from Florida ranged from 900 to 1,008 nucleotides (nt) (Supplementary Table $\mathrm{S} 1$ ). The size of the $\mathrm{CP}$ sequence of the two historical isolates from sugarcane in Louisiana was 915 and $927 \mathrm{nt}$ for strain $\mathrm{A}$ and strain $\mathrm{B}$, respectively. The percentage identity of the $\mathrm{CP}$ nucleotide and amino acid sequences among the 62 SCMV isolates from Florida varied from 73.6 to $100 \%$ and 80.0 to $100 \%$, respectively (Supplementary Fig. S1). At the nucleotide level, the lowest sequence identity $(73.6 \%)$ was observed between isolate SC-Halalii $\mathrm{Ph}$ bis from sugarcane and isolate MZ-1 from maize. At the amino acid level, the lowest sequence identity ( $80.0 \%$ ) was found between isolate DIG-JSP from southern crabgrass and three isolates from Columbus grass (SAL-CP40) and sorghum (SBI-150733 and SBI-651496). The percentage identity of the nucleotide and amino acid $\mathrm{CP}$ sequences among the $27 \mathrm{SCMV}$ isolates retrieved from GenBank (and representing the known genetic variability of the virus) varied from 68.6 to $99.5 \%$ and 71.6 to $99.7 \%$, respectively.

A phylogenetic tree based on the $\mathrm{CP}$ amino acid sequence of the 62 isolates from Florida, 27 isolates retrieved from GenBank, and two sugarcane isolates from Louisiana obtained in this study was constructed to organize similar isolates into clades. The 91 virus isolates were distributed into eight major groups (Fig. 4 and Supplementary Fig. S2). No SCMV Florida isolate occupied clades III, V, and VI. Group I contained 38 isolates of SCMV from sorghum, Columbus

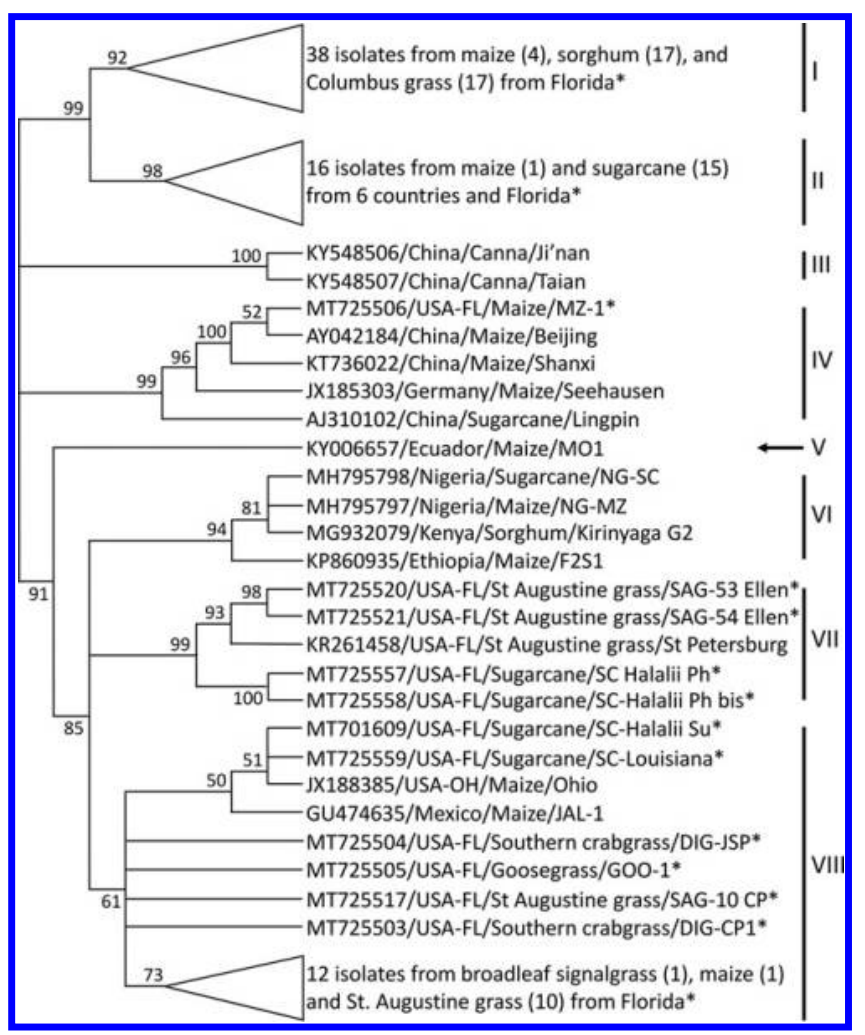

Fig. 4. Phylogenetic tree of sugarcane mosaic virus (SCMV) constructed with the amino acid sequence of the coat protein of 62 virus isolates collected in Florida from eight plant species (Supplementary Table S1) and 29 virus isolates retrieved from GenBank (Supplementary Table S2). The 29 GenBank isolates represent the most recent genetic diversity reported for SCMV (Boukari et al. 2021; Li et al. 2019). The phylogenetic tree was inferred via the maximum likelihood method in MEGA X with substitution model Tamura-Nei selected as the best-fit model. Virus isolates were listed as accession number/country of origin/ host plant/isolate name. The isolates marked with asterisks were obtained in this study. Bootstrap values (1,000 replications) $>50$ are indicated at branches, and branches with bootstrap values $<50$ were collapsed. A detailed tree with names of all isolates is provided in Supplementary Figure S2. grass, and maize, and all were collected in Florida. Three of the four sugarcane isolates from Florida sequenced in this study (SC$2086 \mathrm{Ma}, \mathrm{SC}-2086 \mathrm{Su}$, and SC-2086 EG) were attributed to group II. These three isolates were closest to sugarcane strain E from Florida that was retrieved from GenBank (AY836523). Group II also included pathogenic strains A (AJ278405), B (U57355), and D (U57356) of sugarcane from GenBank, as well as historical strains A and B from Louisiana sequenced in this study. Isolate MZ-1 from maize in Florida was located in group IV and had $99 \%$ nt and amino acid (aa) identity with isolates Beijing and Shanxi from China. Two isolates from sugarcane (SC-Halalii $\mathrm{Ph}$ and $\mathrm{SC}-\mathrm{Halalii} \mathrm{Ph}$ bis) and three isolates from St. Augustine grass (SAG-53 Ellen, SAG54 Ellen, and St. Petersburg) formed group VII. These five isolates were all from Florida, and isolate St. Petersburg was obtained from GenBank (KR261458). Group VIII included 20 isolates, among which 18 originated in Florida and were obtained in this study: two from sugarcane (SC-Halalii Su and SC-Louisiana), two from southern crabgrass (DIG-JSP and DIG-CP1), one from goosegrass (GOO-1), 11 from St. Augustine grass (SAG-10 CP, SAG-EREC3, SAG-1 Sam, etc.), one from maize (MZ-FC1), and one from broadleaf signalgrass (SIG-1). The two isolates of group VIII that did not originate in Florida were both obtained from maize: JAL-1 (GU474635) in Mexico and Ohio (JX188385) in Ohio.

Genetic variability of SCMV in Florida based on the entire genome coding sequence. The size of the complete coding sequence (polyprotein) of the six SCMV isolates from Florida and Louisiana determined by HTS ranged from 9,168 to 9,207 nt (Table 3 ). The size of the polyprotein of the $21 \mathrm{SCMV}$ isolates retrieved from GenBank (and representing the known genetic variability of the virus) varied between 9,165 and 9,237 nt (Supplementary Tables S1 and S2). For these 27 isolates, the size of the complete coding genome without the $\mathrm{CP}$ was always $8,253 \mathrm{nt}$, and the difference in size between the genomes was due only to the varying size of the $\mathrm{CP}$ (912 to $1,008 \mathrm{nt}$ ). The percentage identity of the polyprotein nucleotide and amino acid sequences among all 27 isolates varied from 68.1 to $97.2 \%$ and 82.9 to $99.4 \%$, respectively (Supplementary Fig. S3).

A phylogenetic tree based on the polyprotein sequence of the four isolates from Florida (two from St. Augustine grass and two from sugarcane), two from Louisiana (both from sugarcane), and the 27 isolates retrieved from GenBank was constructed to organize similar isolates into clades. The 33 virus isolates were distributed in eight major groups, and the SCMV Florida isolates were distributed in two (I and IV) of these eight clades (Fig. 5). Group I contained nine isolates of SCMV from sugarcane, Columbus grass, and sorghum. The sugarcane isolates originated from several countries (Argentina, Australia, China, India, and Florida and Louisiana in the United States). The sorghum and maize isolates (which also formed a distinctive subgroup) were both from Florida (CP58 and PI 651496). Four isolates from the United States formed group IV: two isolates from St. Augustine grass (CED and CYP) in Florida, one from sugarcane (SC-Halalii $\mathrm{Su}$ ) in Florida, and isolate Ohio (JX188385) from maize in Ohio.

Comparison of virulence of SCMV from Columbus grass, St. Augustine grass, and sugarcane. In two to six separate inoculation experiments (1 to 6), SCMV from Columbus grass produced

TABLE 3. Size of the polyprotein of six isolates of sugarcane mosaic virus from Florida and Louisiana determined by high-throughput sequencing

\begin{tabular}{llc}
\hline SCMV isolate & \multicolumn{1}{c}{ Plant host } & $\begin{array}{c}\text { Size of } \\
\text { polyprotein (nt) }\end{array}$ \\
\hline SAG-CED & St. Augustine grass (Florida) & 9,186 \\
SAG-CYP & St. Augustine grass (Florida) & 9,207 \\
SC-2086 Su & Sugarcane (Florida) & 9,192 \\
SC-Halalii Su & Sugarcane (Florida) & 9,192 \\
POJ234 strain A & Sugarcane (Louisiana) & 9,168 \\
POJ234 strain B & Sugarcane (Louisiana) & 9,180 \\
\hline
\end{tabular}


mosaic symptoms in $79 \%$ of Columbus grass plants, $71 \%$ of maize plants, $78 \%$ of sorghum plants, $38 \%$ of St. Augustine grass plants, and no sugarcane plants (Table 2). No plants of Columbus grass exhibited mosaic symptoms after inoculation with SCMV from St. Augustine grass. This virus isolate produced symptoms in $100 \%$ of St. Augustine grass plants and $94 \%$ of sugarcane plants. SCMV from sugarcane produced disease symptoms in no Columbus grass plants, $32 \%$ of maize plants, $18 \%$ of sorghum plants, $38 \%$ of St. Augustine grass plants, and $79 \%$ of sugarcane plants (Table 2). All plants inoculated with buffer remained symptomless. In experiments 1 and 2, infection by SCMV was confirmed by RT-PCR (diagnostic primers oligo $1 \mathrm{n}$ and $2 \mathrm{n}$ ) in symptomatic plants of Columbus grass, maize, and sorghum (three plants per experiment and plant species). The virus was not detected by RT-PCR in six symptomless plants of sugarcane. In experiments 3 to 6 , all inoculated plants that exhibited mosaic symptoms were positive by tissue blot immunoassay, whereas all symptomless plants (including control plants inoculated with buffer) tested negative (Table 2).

Genomic features associated with virulence of SCMV from Columbus grass, St. Augustine grass, and sugarcane. Based on infection data described previously, SCMV isolates infecting Columbus grass, St. Augustine grass, and sugarcane showed different virulence patterns. In particular, SCMV from Columbus grass was not able to infect and cause symptoms in sugarcane, and SCMV from sugarcane was avirulent in Columbus grass (Table 2). SCMV from St. Augustine grass was able to infect sugarcane but not Columbus grass. To identify possible genomic explanations for these virulence patterns, the full amino acid genome sequence that was available for SC-2086 Su from sugarcane (MT701608) was first aligned and compared with the corresponding sequence of CP58 (MN714644) from Columbus grass. The two sequences differed by 101 aa mismatches distributed along the genome and a microindel of 9 aa
(PATQGSQPP) in the coat protein gene (Fig. 6). This microindel was an insertion in the genome of SC-2086 and a deletion in the genome of CP58. A total of 99 aa mismatches were found between the sequences of SC-2086 Su and PI 651496 (MN097768) from sorghum that belongs to the same phylogenetic groups as CP58. The 9-aa deletion was also present in the sequence of the SCMV isolate from sorghum, but it corresponded to a 5-aa microindel (PATQG) at the same location in the genome sequence of the two St. Augustine isolates (SAG-CED and SAG-CYP) from Florida (Fig. 6). The same 9-aa microindel was found in the CP sequence of all 38 SCMV isolates from Columbus grass, maize, and sorghum belonging to phylogenetic group I, as well as in the four SCMV isolates from sugarcane in Florida belonging to phylogenetic group II (Fig. 4).

\section{DISCUSSION}

Extensive recombination has resulted in high variability of the SCMV genome and complex phylogenetic histories of this virus, which has been reported in $>80$ countries and affects many hosts (Braidwood et al. 2019). Recent discoveries of new genetic variants and hosts outside the Poaceae family also suggest that SCMV evolution is still in progress ( $\mathrm{Li}$ et al. 2019; Zhao et al. 2019). Hosts with economic importance and susceptible to the virus are usually rapidly identified. However, noncultivated hosts (such as grass weeds or ruderal plants) can be virus reservoirs for infection of cultivated plants, and they are often overlooked. Among the symptomatic plants collected and tested in this study, maize, sorghum, St. Augustine grass, sugarcane, and Columbus grass were known natural hosts of SCMV in Florida (Boukari et al. 2021; Mollov et al. 2016; Saladini and Zettler 1972a, b; Todd 1964). To our knowledge, this study is the first report of SCMV infections in broadleaf signalgrass, goosegrass, and southern crabgrass. The host range of SCMV is probably

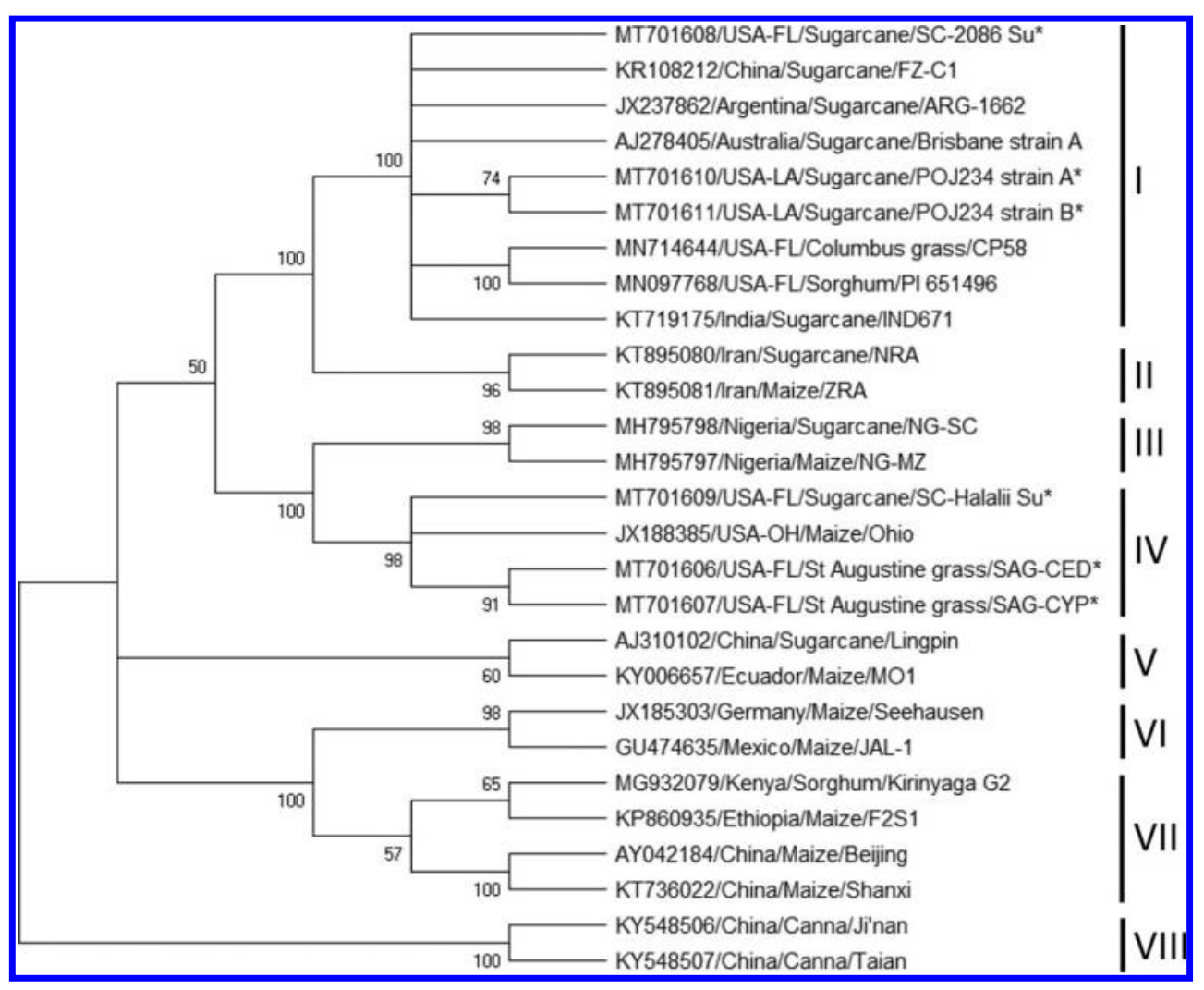

Fig. 5. Phylogenetic tree of sugarcane mosaic virus (SCMV) constructed with the amino acid sequence of the genome coding region of 27 virus isolates. Four isolates were collected in this study in Florida (two from sugarcane and two from St. Augustine grass), and two isolates were collected in this study in Louisiana (both from sugarcane). The remaining 21 isolates were retrieved from GenBank and represent the most recent genetic diversity reported for SCMV (Boukari et al. 2021; Li et al. 2019). The phylogenetic tree was inferred via the maximum likelihood method in MEGA X with substitution model Tamura-Nei selected as the bestfit model. Virus isolates were listed as accession number/country of origin/host plant/isolate name. The isolates marked with asterisks were obtained in this study. Bootstrap values $(1,000$ replications) $>50$ are indicated at branches, and branches with bootstrap values $<50$ were collapsed. 
wider still, because the virus was also reported in Florida in gammagrass and in hairy crabgrass (Saladini and Zettler 1972a).

Cultivated and uncultivated plant species tested positive for SCMV in our study. Cultivated plants were produced on farms (maize, sorghum, and sugarcane) or were grown at private homes (lawns of St. Augustine grass). Uncultivated plants were grass species growing in natural or naturalized areas (broadleaf signalgrass, Columbus grass, goosegrass, southern crabgrass, St. Augustine grass). Diseased sugarcane included plants grown in pots for breeding purposes at the USDA-ARS Sugarcane Field Station at Canal Point, Florida. This finding raised the question whether identical virus populations were present in both cultivated and noncultivated plants and whether grass weeds could be an inoculum reservoir for cultivated plants. SCMV can be spread by mechanical means, planting of infected material, and several aphid species.

All Florida isolates of SCMV collected from Columbus grass and sorghum (and some of maize) formed a unique genetic group based on their $\mathrm{CP}$ sequence. Among those, one representative isolate from Columbus grass and one from sorghum also formed a single phylogenetic subgroup based on the entire genome coding sequence, as previously reported by Boukari et al. (2021). This finding suggested that the same virus strain was naturally spreading in the EAA between Columbus grass, sorghum, and maize. SCMV from Columbus grass was unable to infect sugarcane after mechanical transmission and vice versa, thus showing that mosaic disease in sugarcane and sorghum is caused by two different genetic and pathogenic strains of the virus in south Florida. Consequently, Columbus grass, which is a robust and widespread perennial in south Florida and grows in proximity to commercial sugarcane fields, does not appear to be a reservoir for viruses causing sugarcane mosaic in the EAA.

In the last decade, sugarcane grown in the EAA was not affected by mosaic, and SCMV was not detected in commercial fields by Filloux et al. (2018) in samples collected in 2013 to 2014. The sugarcane samples investigated in our study came from disease trials and from potted plants used for breeding purposes at the USDA Sugarcane Field Station at Canal Point, Florida. These plants were found infected by three different genetic types of the virus. The first type (represented by isolates SC-2086 Ma, SC-2086 Su, and SC-2086 EG) showed high CP sequence identity (99.4\% at the nucleotide level) with SCMV strain E from sugarcane in Florida that was available in GenBank (accession number 838523). These isolates were also distributed in the same phylogenetic groups (II based on the $\mathrm{CP}$ or I based on the entire genome) that included SCMV isolates from sugarcane collected in numerous countries, including pathogenic strains A, B, and D and the two historical isolates from Louisiana. These isolates and strains were responsible for mosaic epidemics in sugarcane around the world (Alegria et al. 2003; Grisham 2000; Koike and Gillaspie 1989; Yang and Mirkov 1997). The second genetic type (represented by isolates SC-Halalii $\mathrm{Ph}$ and $\mathrm{SC}-\mathrm{Halalii} \mathrm{Ph}$ bis) formed a unique phylogenetic group with three isolates from St. Augustine grass (group VII based on CP). The third genetic type (represented by isolates SC-Halalii $\mathrm{Su}$ and SC-Louisiana) was found in phylogenetic groups (VIII based on the CP and IV based on the entire genome) that also included isolates from wild species of Poaceae (broadleaf signalgrass, goosegrass, southern crabgrass, St. Augustine grass). The sugarcane plants infected by SCMV genetic types 2 and 3 were in breeding pots in an open space at Canal Point and were established from cuttings that were collected from disease-free field plots. This finding suggested that the potted plants became infected after planting and that genetic types 2 and 3 of SCMV in sugarcane originated from one or more wild species of Poaceae, including St. Augustine grass. Consequently, wild species of Poaceae could be the source of new epidemics of sugarcane in Florida if varieties susceptible to mosaic were to be released for commercial production or if infected plants were not removed from nurseries used for commercial planting.

In our study, SCMV from St. Augustine grass was able to infect sugarcane after mechanical transmission, and St. Augustine grass showed mosaic symptoms after inoculation with the virus from sugarcane. These data confirmed previous results reported by Todd (1964) when mosaic was first discovered in 1963 on common St. Augustine grass at the USDA-ARS Sugarcane Field Station at Canal Point, Florida. After inoculation of sugarcane varieties used to identify strains of SCMV, the virus from St. Augustine grass was considered to be an undescribed and therefore new strain of the virus (Todd 1964). The genetic type of SCMV responsible for decades for mosaic epidemics in sugarcane around the world (including Florida, as discussed previously) was not found in St. Augustine grass in our study. This suggested that if the spread of the virus occurs between these two plant species under natural conditions, it is from St. Augustine grass to sugarcane rather than from sugarcane to St. Augustine grass. Interestingly, SCMV from Columbus grass was able to infect St. Augustine grass after mechanical transmission, but the converse did not occur, that is, Columbus grass was not infected with SCMV from St. Augustine grass. Virus isolates hosted by these two plant species in Florida were also genetically different, suggesting that natural spread does not occur between Columbus grass and St. Augustine grass in the EAA.

Sorghum, sugarcane, and St. Augustine grass appeared to be infected by specific populations of SCMV in south Florida, suggesting absence of, or only limited, natural interspecies transmission between these host plants. The capacity of aphids to move from one plant species to another is a key factor in the spread of SCMV among and between cultivated and wild grasses. Maize, sugarcane, and a weed host, itch grass (Rottboellia cochinchinensis [Lour.] W.D. Clayton) were recently reported infected by the same genetic populations of the virus in Nigeria, suggesting that interspecies transmission in this country was caused by aphid vectors probing or feeding on all three plant species (Yahaya et al. 2019). A similar situation was reported in Iran, where sugarcane, maize, sorghum, and johnsongrass were infected by genetically closely related isolates of SCMV (Moradi et al. 2017). In the EAA, this interspecies spread seems to happen mainly between the wild sorghum, Columbus grass, and cultivated sorghum or maize varieties.

Maize was the only host plant in south Florida that was found infected by isolates belonging to three different phylogenetic groups

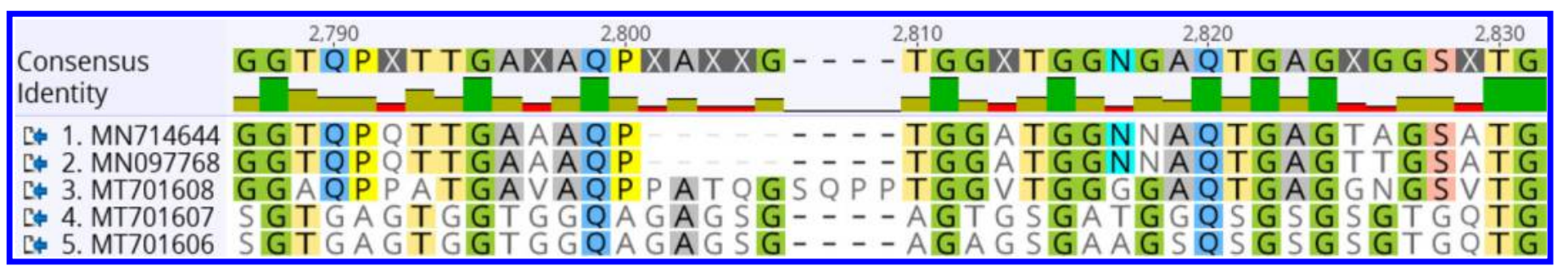

Fig. 6. Comparison of the amino acid (aa) sequence of the genome of five isolates of sugarcane mosaic virus from Columbus grass, St. Augustine grass, sorghum,

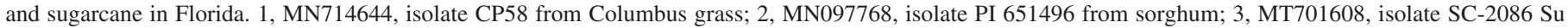

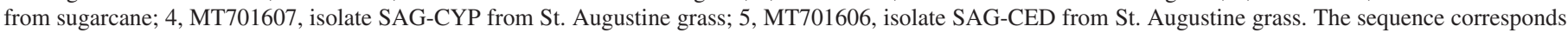

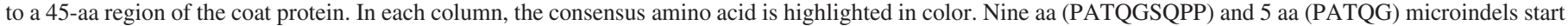
at position 2801 
(CP-based groups I, IV, and VIII), and this plant can be infected by a wide genetic range of SCMV isolates or strains (Alegria et al. 2003; Redinbaugh and Stewart 2018; Yahaya et al. 2019). Indeed, when we considered isolates from all over the world, isolates from this host plant were found in almost all phylogenetic groups. The only exceptions are the absence, to date, of maize isolates in CP group VII formed by St. Augustine grass and sugarcane isolates from Florida and in group III formed by the two isolates from canna in China (Tang et al. 2018). However, the SCMV isolated from canna has been considered a recombinant strain with one parent infecting maize ( $\mathrm{Li}$ et al. 2019). The correlation between SCMV and maize was also higher than the correlation between SCMV and sugarcane in a study based on the codon usage patterns of the virus (He et al. 2020). The capacity of maize to host a great diversity of SCMV strains may also be associated with an aphid vector such as the corn leaf aphid Rhopalosiphum maydis, which has a worldwide distribution, is found in cultivated fields and grasslands, and feeds on a wide range of monocots (Blackman and Eastop 2000). In Florida, an SCMV isolate from St. Augustine grass was transmitted from maize to maize with $R$. maydis (Saladini and Zettler 1972b). Further investigations into genetic and pathogenic variations of SCMV in Florida and elsewhere should therefore also include vector biology experiments.

The molecular basis for host specificity of SCMV isolates is currently unknown. Several regions of the $\mathrm{CP}$ play critical roles in cell-to-cell movement of potyviruses (Yan et al. 2021). In this study, we identified two microindels that differentiated isolates infecting Columbus grass, St. Augustine grass, and sugarcane. These microindels located in the CP sequence could be targeted in functional genomics to decipher molecular host specificity in SCMV, one of the most widespread and economically damaging viruses in the world.

\section{ACKNOWLEDGMENTS}

We thank Robert Beiriger, Wardatou Boukari, Henri Victor Espinoza, Sam Glucksman, Philip Harmon, Adrian Hughes, Eva Mulandesa, Richard Raid, Stewart Swanson, Lihua Tang, and Chunyan Wei for their help in collecting plants with mosaic symptoms; Ken Peterkin and Michelle Incledon for their help during inoculation of plants with SCMV; and Gary Kinard for critical review of the manuscript.

\section{LITERATURE CITED}

Alegria, O. M., Royer, M., Bousalem, M., Chatenet, M., Peterschmitt, M., Girard, J.-C., and Rott, P. 2003. Genetic diversity in the coat protein coding region of eighty-six sugarcane mosaic virus isolates from eight countries, particularly from Cameroon and Congo. Arch. Virol. 148:357-372.

Baker, C. A., Wilber, L. J., and Jones, L. 2010. A new host diagnosed with a strain of Sugarcane mosaic virus in Florida: red-veined prayer plant (Maranta leuconeura erythroneura). Plant Dis. 94:378-379.

Blackman, R. L., and Eastop, V. F. 2000. Aphids on the World's Crops: An Identification and Information Guide. John Wiley \& Sons, Chichester, England.

Boukari, W., Mollov, D., Wei, C., Tang, L., Grinstead, S., Tahir, M. N., Mulandesa, E., Hincapie, M., Beiriger, R., and Rott, P. 2021. Screening for sugarcane yellow leaf virus in sorghum in Florida revealed its occurrence in mixed infections with sugarcane mosaic virus and a new marafivirus. Crop Prot. 139:105373.

Braidwood, L., Müller, S. Y., and Baulcombe, D. 2019. Extensive recombination challenges the utility of Sugarcane mosaic virus phylogeny and strain typing. Sci. Rep. 9:20067.

Chung, B. Y.-W., Miller, W. A., Atkins, J. F., and Firth, A. E. 2008. An overlapping essential gene in the Potyviridae. PNAS 105:5897-5902.

de Souza, I. R. P., Giolitti, F., Carneiro, N. P., Lenardon, S. L., de Oliveira, E., Gomes, E. A., Noda, R. W., and de Souza, F. A. 2012. Sequence diversity in the coat protein of SCMV infecting maize and sorghum in Brazil. Rev. Bras. Milho Sorgo 11:120-136.

Dean, J. L. 1963. Effect of air pressure, abrasives and distance from spray nozzle to plants on infection of sugarcane seedlings with mosaic virus. Proc. Int. Soc. Sugar Cane Technol. 11:748-752.

Filloux, D., Fernandez, E., Comstock, J. C., Mollov, D., Roumagnac, P., and Rott, P. 2018. Viral metagenomic-based screening of sugarcane from Florida reveals occurrence of six sugarcane-infecting viruses and high prevalence of Sugarcane yellow leaf virus. Plant Dis. 102:2317-2323.
Gómez, M., Rago, A. M., and Serino, G. 2009. Rapid identification of viruses causing sugarcane mosaic by direct sequencing of RT-PCR products from crude extracts: a method for large scale virus surveys. J. Virol. Methods 157:188-194.

Grisham, M. P. 2000. Mosaic. Pages 249-254 in: A Guide to Sugarcane Diseases. P. Rott, R. A. Bailey, J. C. Comstock, B. J. Croft, and A. S. Saumtally, eds. La Librairie du Cirad, Montpellier, France.

Handley, J. A., Smith, G. R., Dale, J. L., and Harding, R. M. 1998. Sequence diversity in the coat protein coding region of twelve sugarcane mosaic potyvirus isolates from Australia, USA and South Africa. Arch. Virol. 143:1145-1153.

Harmon, P. 2015. Mosaic disease of St. Augustinegrass caused by sugarcane mosaic virus. University of Florida/Institute of Food and Agricultural Sciences EDIS paper PP313.

Harmon, P. F., Alcalá-Briseño, R. I., and Polston, J. E. 2015. Severe symptoms of mosaic and necrosis in cv. Floratam St. Augustinegrass associated with Sugarcane mosaic virus in neighborhoods of St. Petersburg, FL. Plant Dis. 99:557.

-He, Z., Dong, Z., and Gan, H. 2020. Genetic changes and host adaptability in sugarcane mosaic virus based on complete genome sequences. Mol. Phylogenet. Evol. 149:106848.

Koike, H., and Gillaspie, A. G., Jr. 1989. Mosaic. Pages 301-322 in: Diseases of Sugarcane; Major Diseases. C. Ricaud, B. T. Egan, A. G. Gillaspie, Jr., and C. G. Hughes, ed. Elsevier, Amsterdam, The Netherlands.

Kumar, S., Stecher, G., Li, M., Knyaz, C., and Tamura, K. 2018. MEGA X: Molecular Evolutionary Genetics Analysis across computing platforms. Mol. Biol. Evol. 35:1547-1549.

Li, Y., Xia, F., Wang, Y., Yan, C., Jia, A., and Zhang, Y. 2019. Characterization of a highly divergent Sugarcane mosaic virus from Canna indica L. by deep sequencing. BMC Microbiol. 19:260.

-Lin, N. S., Hsu, Y. H., and Hsu, H. T. 1990. Immunological detection of plant viruses and a mycoplasma-like organism by direct tissue blotting on nitrocellulose membranes. Phytopathology 80:824-828.

Marie-Jeanne, V., Ioos, R., Peyre, J., Alliot, B., and Signoret, P. 2000. Differentiation of Poaceae potyviruses by reverse transcription-polymerase chain reaction and restriction analysis. J. Phytopathol. 148:141-151.

Mollov, D., Tahir, M. N., Wei, C., Kaye, C., Lockhart, B., Comstock, J. C., and Rott, P. 2016. First report of Sugarcane mosaic virus infecting Columbus grass (Sorghum almum) in the United States. Plant Dis. 100:1510.

Moradi, Z., Nazifi, E., and Mehrvar, M. 2017. Occurrence and evolutionary analysis of coat protein gene sequences of Iranian isolates of Sugarcane mosaic virus. Plant Pathol. J. 33:296-306.

Redinbaugh, M. G., and Stewart, L. R. 2018. Maize lethal necrosis: an emerging, synergistic viral disease. Annu. Rev. Virol. 5:301-322.

Saladini, J. L., and Zettler, F. W. 1972a. Survey for viral diseases of St. Augustinegrass in Florida. Plant Dis. Rep. 56:822-823.

Saladini, J. L., and Zettler, F. W. 1972b. Characterization of strain E of sugarcane mosaic virus infecting St. Augustinegrass. Plant Dis. Rep. 56:885-889.

Schenck, S., Hu, J. S., and Lockhart, B. E. L. 1997. Use of a tissue blot immunoassay to determine the distribution of Sugarcane yellow leaf virus in Hawaii. Sugar Cane 4:5-8.

Srisink, S., Taylor, P. W. J., Stringer, J. K., and Teakle, D. S. 1994. An abrasive pad rubbing method for inoculating sugarcane with sugarcane mosaic virus. Aust. J. Agric. Res. 45:625-631.

Tamura, K., and Nei, M. 1993. Estimation of the number of nucleotide substitutions in the control region of mitochondrial DNA in humans and chimpanzees. Mol. Biol. Evol. 10:512-526.

Tang, W., Yan, Z.-Y., Zhu, T.-S., Xu, X.-J., Li, X.-D., and Tian, Y.-P. 2018. The complete genomic sequence of Sugarcane mosaic virus from Canna spp. in China. Virol. J. 15:147.

Todd, E. H. 1964. Sugarcane mosaic on St. Augustinegrass in Florida. Plant Dis. Rep. 48:442.

Wamaitha, M. J., Nigam, D., Maina, S., Stomeo, F., Wangai, A., Njuguna, J. N., Holton, T. A., Wanjala, B. W., Wamalwa, M., Lucas, T., Djikeng, A., and Garcia-Ruiz, H. 2018. Metagenomic analysis of viruses associated with maize lethal necrosis in Kenya. BMC Virol. J. 15:90.

Xie, X., Chen, W., Fu, Q., Zhang, P., An, T., Cui, A., and An, D. 2016. Molecular variability and distribution of Sugarcane mosaic virus in Shanxi, China. PLoS One 11:e0151549.

-Yahaya, A., Dangora, D. B., Kumar, P. L., Alegbejo, M. D., Gregg, L., and Alabi, O. J. 2019. Prevalence and genome characterization of field isolates of sugarcane mosaic virus (SCMV) in Nigeria. Plant Dis. 103:818-824.

Yan, Z.-Y., Xu, X.-J., Fang, L., Cheng, D.-J., Tian, Y.-P., Geng, C., Li, X.-D., Valkonen, J. P. T. 2021. Residues $\mathrm{R}^{192}$ and $\mathrm{K}^{225}$ in RNA-binding pocket of tobacco vein banding mosaic virus $\mathrm{CP}$ control virus cell-to-cell movement and replication. Mol. Plant Microbe Interact. doi:10.1094/MPMI-09-20-0265-R

-Yang, Z. N., and Mirkov, T. E. 1997. Sequence and relationships of sugarcane mosaic and sorghum mosaic virus strains and development of RT-PCRbased RFLPs for strain discrimination. Phytopathology 87:932-939.

Zhao, H., Zhang, H., Yang, Z. T., Wang, T., Liu, Y. J., Cheng, G. Y., and Xu, J. S. 2019. First report of sugarcane mosaic virus on pumpkin plants exhibiting mosaic and mottling symptoms in China. Plant Dis. 103:1802. 